
RESEARCH AND DEVELOPMENT

\author{
http://journal.unnes.ac.id/sju/index.php/higeia
}

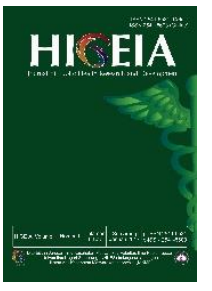

\title{
PENGETAHUAN RISIKO PERNIKAHAN DINI PADA REMAJA UMUR 13-19 TAHUN
}

\author{
Eka Radiyani Oktavia ${ }^{凶}$, Fatehah Rahma Agustin, Nandito Mapian Magai, Sigit Ambar \\ Widyawati, Widya Hary Cahyati
}

Program Studi Kesehatan Masyarakat, Fakultas Ilmu Kesehatan, Universitas Ngudi Waluyo

\begin{tabular}{l}
\hline Info Artikel \\
\hline Sejarah Artikel: \\
Diterima Februari 2018 \\
Disetujui Maret 2018 \\
Dipublikasikan April \\
2018 \\
\hline Keywords: \\
Knowledge, Early Marriage, \\
Youth
\end{tabular}

\begin{abstract}
Abstrak
Hasil survei awal pada bulan September tahun 2017 yang dilakukan pada 30 orang remaja putri di Kelurahan Pudak Payung, ditemukan 4 orang remaja putri (13,3\%) yang kurang mengerti tentang risiko pernikahan dini. Hal ini berimplikasi pada tingginya kejadian usia pernikahan dini dibawah umur 20 tahun, padahal di Kota Semarang sudah ada kebijakan tentang Kota Layak Anak. Penelitian ini bertujuan untuk mengetahui gambaran pengetahuan risiko pernikahan dini pada remaja usia 13-19 tahun di Kelurahan Pudak Payung. Penelitian ini menggunakan metode penelitian deskriptif kuantitatif dengan Kelurahanin penelitian cross sectional. Kegiatan penelitian ini dilaksanakan pada tanggal 22 November 2017 yang dilakukan di Lingkungan RW 06 Kelurahan Pudak Payung Kota Semarang. Sampel penelitian ini berjumlah 30 responden. Instrumen penelitian menggunakan kuosioner, dokumentasi dan observasi. Hasil penelitian menunjukan bahwa responden yang berpengetahuan baik sebanyak 2 responden ( $8 \%$ ), cukup sebanyak 23 responden (78\%), dan kurang sebanyak 5 responden (14\%). Simpulan dari penelitian ini adalah tingkat pengetahuan remaja usia 13-19 tahun di Kelurahan Pudak Payung mayoritas tergolong berpengetahuan cukup dengan presentase $78 \%$, dipengaruhi oleh rendahnya pendidikan remaja dan pemahaman dari remaja yang minim.
\end{abstract}

\begin{abstract}
Survey results in September 2017 conducted on 30 young women in Pudak Umbrella Village, found 4 young women (13.3\%) who did not understand about the risk of early marriage. This had implications for the high incidence of early marriage age under 20 years, whereas in Semarang City there was already a policy on Child Friendly City. This study aimed to determine the image of early marriage risk knowledge in adolescents aged 13-19 years in Pudak Payung Urban Village. This research used descriptive quantitative research method with cross sectional study. This research activity was conducted on November 22nd, 2017 which was done in Neighborhood RW 06 Pudak Payung Urban Village Semarang. The sample of this study amounted to 30 respondents. The research instrument used questionnaires, documentation and observation. The results showed that respondents who were well knowledge as much as 2 respondents (8\%), quite as much as 23 respondents (78\%), and less as many as 5 respondents (14\%). The conclusion of this research was the level of knowledge of adolescents aged 13-19 years in Pudak Payung Village majority classified as knowledgeable enough with percentage $78 \%$, influenced by low education of adolescents and understanding of teenagers minimal.
\end{abstract}

(C) 2018 Universitas Negeri Semarang 


\section{PENDAHULUAN}

Secara hukum perkawinan usia anak telah dilegitimasi dengan adanya Undangundang RI Nomor 1 Tahun 1974 tentang Perkawinan. Undang-undang tersebut memperbolehkan anak berusia 16 tahun untuk menikah, seperti disebutkan dalam pasal 7 ayat 1, "Perkawinan hanya diizinkan jika pihak pria sudah mencapai 19 tahun, dan pihak wanita sudah mencapai 16 tahun." Sedangkan Pasal 26 UU RI Nomor 23 Tahun 2002 tentang Perlindungan Anak menyebutkan bahwa orang tua diwajibkan melindungi anak dari perkawinan dini. Tetapi kedua pasal tersebut tidak memiliki ketentuan sanksi pidana sehingga ketentuan tersebut nyaris tidak ada artinya dalam melindungi anak-anak dari ancaman perkawinan dini (KPP\&PA, 2012).

Indonesia merupakan negara yang mempunyai kebijakan Kota Layak Anak (KLA) di beberapa kabupaten atau kotanya. Salah satu indikatornya adalah tidak ada perkawinan anak atau perkawinan di bawah umur 18 tahun. Namun pada kenyataannya, Indonesia tidak lepas dari kejadian pernikahan di bawah umur atau usia remaja (KPP\&PA, 2012). Menurut data Kementerian Pemberdayaan Perempuan dan Perlindungan Anak (KPP\&PA) dalam Profil Anak Indonesia 2012, sebesar 1,62 persen anak perempuan di bawah umur 18 tahun di Indonesia berstatus kawin dan pernah kawin, sedangkan di Jawa Tengah sebesar 1,47 persen anak perempuan di bawah umur 18 tahun di Indonesia berstatus kawin dan pernah kawin (KPP\&PA, 2012). Permasalahan kesehatan reproduksi dimulai dengan adanya pernikahan dini yang hasilnya yaitu pada perempuan usia 10-54 tahun terdapat 2,6 persen menikah pada usia kurang dari 15 tahun kemudian 23,9 persen menikah pada usia 15-19 tahun (Kemenkes RI, 2013).

Perilaku seksual merupakan faktor yang sangat mempengaruhi terjadinya kehamilan usia remaja (Dewi, 2012). Remaja adalah masa peralihan dari masa anak-anak menuju masa dewasa, yakni antara usia 10 tahun sampai 19 tahun. Masa remaja yang perlu di perhatikan adalah usia 13-15 tahun (Anas, 2010). Usia remaja menimbulkan berbagai persoalan dari berbagai sisi seperti remaja yang selalu ingin coba-coba, pendidikan rendah, pengetahuan yang minim, pekerjaan yang sulit didapat sehingga dampaknya berpengaruh terhadap pendapatan ekonomi keluarga. Terlebih lagi jika mereka menikah di usia muda karena keterlanjuran berhubungan seksual sehingga menimbulkan suatu kehamilan. Adanya penolakan keluarga yang terjadi akibat malu, hal ini dapat menyebabkan stress berat. Ibu hamil usia muda lebih banyak memiliki risiko bunuh diri lebih tinggi (Bahar, 2014).

Tingginya angka perkawinan anak menimbulkan berbagai masalah kesehatan diantaranya ibu yang berusia dibawah 18 tahun yaitu memiliki $35 \%$ hingga $55 \%$ risiko yang lebih tinggi untuk melahirkan bayi dengan berat bayi lahir rendah (BBLR) dibandingkan dengan ibu yang berusia diatas 19 tahun. Angka kematian bayi $60 \%$ lebih tinggi pada ibu yang masih berusia dibawah 18 tahun. Hasil penelitian menunjukkan bahwa setelah anak dari ibu muda bertahan hidup hingga tahun pertama, anak dibawah 5 tahun memiliki 28\% risiko kematian yang lebih besar. Kejadian kesakitan dan kematian ini diakibatkan oleh nutrisi ibu yang kurang baik, fisik dan psikis ibu yang belum matang, kurangnya akses bermasyarakat dan akses pelayanan kesehatan reproduksi dan risiko tinggi akan penyakit infeksi (Nour, 2009). Bayi yang dilahirkan oleh ibu dengan usia kurang dari 20 tahun juga berisiko lahir prematur, berat bayi lahir rendah (BBLR), serta kelainan bawaan atau cacat yang sudah terjadi sejak dalam proses kehamilan (BKKBN, 2010).

Kasus BBLR di Jawa Tengah pada tahun 2013 menurut Profil Kesehatan Jawa Tengah mencapai angka 21.573 bayi. Selain tingginya angka BBLR pasangan pernikahan dini juga merupakan salah satu penyumbang tingginya Angka Kematian Bayi dimana di Jawa tengah kasus kematian bayi mencapai 10,75/1000 angka kelahiran hidup dan sudah melampaui batas MDG's dimana 17/1000 angka kelahiran hidup (Kemenkes RI, 2013). 
Penelitian yang dilakukan oleh IPADI (Ikatan Peminat dan Ahli Demografi Indonesia) melalui lembaga kependudukan dan BKKBN tahun 2003 menunjukkan saat ini jumlah usia remaja (12-24 tahun) di Indonesia 42 juta (sekitar $20 \%$ dari penduduk Indonesia yang berjumlah 213 juta jiwa). Dari angka ini 35\% adalah pasangan suami isteri, dan dari angka ini sekitar $52 \%$ perempuan telah menikah. Ratarata usia pernikahan pertama di Indonesia adalah usia 19 tahun bagi penduduk yang sekarang berusia 20-24 tahun. Bagi penduduk usia 25 - 29 tahun menikah pada usia 15 tahun adalah $11 \%$, menikah pada usia 18 tahun adalah $18 \%$ dan pada usia menikah 20 tahun sebesar $51 \%$ (BKKBN, 2010).

Di Indonesia diperkirakan angka pertumbuhan penduduknya sebesar $2,5 \%$. Dengan pertumbuhan penduduk 2,5\% setahun, bila terjadi terus menerus maka dalam waktu 28 tahun jumlah penduduk Indonesia akan menjadi dua kali lipat. Selain itu faktor kehamilan remaja juga merupakan penyebab meningkatnya pertumbuhan penduduk, di Indonesia $34,5 \%$ rata-rata nasional remaja melakukan pernikahan dini karena kehamilan remaja (BKKBN, 2010).

Penyebab pernikahan usia dini antara lain pemaksaan dari pihak orang tua, pergaulan bebas, rasa keingintahuan tentang dunia seks, faktor lingkungan, rendahnya pendidikan, faktor ekonomi . Ditinjau dari masalah sosial ekonomi adalah pernikahan usia dini biasanya tidak diikuti dengan kesiapan keadaan ekonomi. Semakin bertambah umur seseorang kemungkinan untuk kematangan dalam bidang social ekonomi juga akan semakin nyata karena pada umumnya dengan bertambahnya umur akan semakin kuat dorongan untuk mencari nafkah penopang. Pada pernikahan usia dini permasalahan ekonomi akan menjadi alasan utama terjadinya perceraian (Fadlyana, 2009).

Hasil survei awal pada bulan September tahun 2017 yang dilakukan pada 30 orang remaja putri di Kelurahan Pudak Payung, ditemukan 4 orang remaja putri $(13,3 \%)$ yang kurang mengerti tentang risiko pernikahan dini. Hal ini berimplikasi pada tingginya kejadian usia pernikahan dini dibawah umur 19 tahun di
Kelurahan Pudak Payung, padahal di Kota Semarang sudah ada kebijakan tentang Kota Layak Anak.

Tujuan penelitian ini adalah untuk mengetahui pengetahuan risiko pernikahan dini pada remaja sehingga dapat menghindari kejadian pernikahan dini.

\section{METODE}

Jenis penelitian yang digunakan dalam penelitian ini adalah deskriptif kuantitatif dengan rancangan cross sectional. Penelitian dilakukan dengan membagikan kuesioner kepada remaja untuk mengetahui pengetahuan risiko pernikahan dini pada remaja. Penelitian yang digunakan merupakan penelitian yang paling sederhana karena peneliti tidak mengubah, menambah dan memanipulasi obyek yang diteliti. Dalam penenlitian ini peneliti meneliti pengetahuan remaja yang berusia $13-19$ tahun. Lokasi yang dipilih untuk menjadi tempat penelitian tentang pengetahuan risiko pernikahan dini pada remaja yaitu di lingkungan RW 06 Kelurahan Pudak Payung, Alasan peneliti melakukan penelitian di Kelurahan tersebut karena populasi dan sampel yang mencukupi, di daerah Pudak Payung masih banyak pernikahan dini pada remaja putri dan kurangnya pemahaman pengetahuan tentang risiko pernikahan dini pada remaja di daerah tersebut.

Variabel bebas dalam penelitian ini yaitu pengetahuan remaja tentang risiko pernikahan dini sedangkan subvariabelnya adalah tingkat pendidikan, pekerjaan keluarga (orang tua), akses terhadap informasi dan lingkungan keluarga. Adapun variabel terikatnya adalah pernikahan dini pada remaja umur 13-19 tahun.

Penelitian ini dilakukan pada tanggal 22 November 2017. Populasi dalam penelitin ini adalah seluruh remaja yang belum menikah, di lingkungan RW 06 Kelurahan Pudak Payung pada tahun 2017 yang berjumlah sebanyak 40 orang. Penelitian ini menggunakan sampel sebanyak 30 responden orang. Teknik pengambilan sampel menggunakan teknik sampel jenuh yaitu dengan teknik penentuan 
sampel dengan cara mengambil semua anggota populasi menjadi sampel. Metode pengumpulan data menggunakan data primer melalui pembagian kuesioner kepada sampel secara langsung. Kuosioner diberikan kepada remaja yang berada di lingkungan RW 06 Kelurahan Pudak Payung dengan meminta kesediaan remaja menjadi responden setelah itu memberi penjelasan secara singkat tentang pengisian kuosioner. Data sekunder dalam penelitian diperoleh dari data jumlah remaja berumur 13 sampai 19 tahun di Kelurahan Pudak Payung RW 06.

Instrumen penelitian ini menggunakan lembar kuesioner. Kuesioner yang digunakan dalam penelitian ini menggunakan kuesioner tertutup mengenai pengetahuan remaja umur 13-20 tahun tentang risiko pernikahan dini, sehingga responden hanya memilih jawaban yang menurut mereka benar. Responden hanya tinggal memilih $\mathrm{a}, \mathrm{b}$ atau $\mathrm{c}$ pada lembar kuesioner dengan menyilang (X) pada jawaban yang dipilih. Untuk pernyataan yang jawaban benar diberi nilai 1 dan jawaban yang salah diberi nilai 0 . Teknik pengambilan data yang digunakan dalam penelitian ini dilakukan melalui pembagian kuesioner, observasi dan dokumentasi

Analisis data yang digunakan dalam penelitian ini adalah analisis univariat. Analisi Univariat dipilih untuk menganalisis setiap variabel hasil dari penelitian untuk menghasilkan distribusi frekuensi dan presentase dari setiap variabel data yang didapat dan diteliti. Analisa selanjutnya dilanjutkan dengan membahas hasil penelitian sesuai dengan teori dan kepustakaan yang ada, sehingga dihasilkan data yang menggambarkan pernikahan dini di daerah penelitian secara jelas.

\section{HASIL DAN PEMBAHASAN}

Hasil penelitian yang dilakukan mengenai pengetahuan risiko pernikahan dini pada remaja di lingkungan RW 06 Pudak Payung yang berjumlah 30 sampel remaja dapat dilihat pada tabel 1.
Tabel 1. Distribusi Frekuensi Pengetahuan Responden tentang Risiko Pernikahan Dini pada remaja di Lingkungan RW 06 Kelurahan Pudak Payung Tahun 2017

\begin{tabular}{cccc}
\hline & Kategori & Frekuensi & $\begin{array}{c}\text { Persentase } \\
(\%)\end{array}$ \\
\hline Pengetahuan & Baik & 2 & 8 \\
& Cukup & 23 & 78 \\
& Kurang & 5 & 14 \\
\hline Jumlah & & 30 & 100,0 \\
\hline
\end{tabular}

Berdasarkan tabel distribusi frekuensi pengetahuan responden tentang risiko pernikahan dini pada remaja di lingkungan RW 06 Pudak Payung mengenai pengetahuan risiko pernikahan dini pada remaja menunjukkan bahwa dominan berpengetahuan cukup yaitu sebanyak 23 orang $(78 \%)$, remaja dengan tingkat pengetahuan kurang sebanyak 5 orang (14\%) dan remaja dengan pengetahuan baik yaitu sebanyak 2 orang (8\%). Faktor-faktor pendorong terjadinya pernikahan pada usia muda di lokasi penelitian ini yaitu antara lain ada faktor ekonomi, faktor keluarga, faktor pendidikan, faktor kemauan sendiri, dan faktor adat setempat.

Setiap manusia memiliki tingkat pengetahuan yang berbeda-beda. Tingkatan pengetahuan dimulai dari tahu (know), memahami (comprehension), aplikasi (application), analisis (analysis), sintesis (syntesis) dan evaluasi (evaluation). Semakin tinggi tingkat pengetahuan seseorang maka semakin tinggi pula kemampuan individu tersebut di dalam melakukan penilaian terhadap suatu materi atau objek. Penilaian tersebut inilah yang akan menjadi landasan seseorang untuk bertindak yang dapat mempengaruhi tingkat pengetahuan adalah pendidikan, umur, lingkungan dan sosial budaya. Semakin tinggi tingkat pendidikan dan status sosial seseorang maka tingkat pengetahuannya akan semakin tinggi pula. Begitu juga dengan umur, semakin bertambahnya umur seseorang maka pengetahuannya juga semakin bertambah. Ada hubungan antara tingkat pengetahuan dengan perilaku. Anak yang mempunyai pengetahuan yang baik maka ada kecenderungan untuk berperilaku yang baik pula (Diaz, 2017). 
Berdasarkan hasil pengetahuan didapatkan bahwa keadaan sosial ekonomi keluarga responden masih tergolong rendah dan belum bisa mencukupi kebutuhan hidup seharihari. Remaja yang menjadi responden mayoritas memiliki tingkat pendidikan yang rendah, demikian pula dengan latar belakang pendidikan orang tuanya. Hal ini sejalan dengan penelitian Anas (2010) yang menyebiutkan bahwa pengetahuan, dan keadaan social ekonomi berhubungan dengan pernikahan di usia dini.

Selain itu, di daerah Pudak Payung ini juga ditemukan kebiasaan orang tua yang mempersiapkan atau mencarikan jodoh untuk anaknya menyebabkan banyaknya anak atau remaja yang putus sekolah atau tidak melanjutkan studi pendidikannya dan justru menikah di usia dini. Selanjutnya, berdasarkan penelitian ditemukan pula adat atau kepercayaan masyarakat menikah di usia dini. Hal yang melatarbelakangi pernikahan usia remaja usia 13-20 tahun adalah adanya ketakutan orang tua terhadap gunjingan dari tetangga dekat, yang beranggapan bahwa apabila anak perempuan belum menikah maka takut jika anaknya nanti dikatakan perawan tua. Penelitian Yulianti (2010) menyebutkan bahwa masih banyak adat atau kepercayaan masyarakat yang menjadi pendorong pernikahan di usia dini.

Selain faktor keadaan sosial ekonomi, pendidikan, dan kebiasaan atau kepercayaan yang dimiliki oleh masyarakat juga terdapat faktor internal yang menyebabkan remaja menikah di usia dini yaitu faktor kemauan diri sendiri. Hal ini dilatarbelakangi karena pergaulan bebas sehingga mereka dapat melakukan pernikahan di usia muda dan kurangnya pengawasan peran orang tua untuk anaknya. Oleh karenanya, mereka atau remaja dengan pergaulan bebas akan bersikap seenaknya bahkan bisa bertindak ke hal negatif seperti seks bebas dan menyebabkan kehamilan di usia dini. Untuk menutupi rasa malu keluarga, maka remaja pun terpaksa harus menikah di usia muda. Penelitian Susilo (2014) menyebutkan bahwa seks bebas menjadi salah satu faktor penyebab pernikahan dini dan aborsi, hal ini dilakukan untuk menutup rasa malu keluarga terhadap cemoohan dari orang yang ada di sekitarnya.

Pengetahuan sangat erat hubungannya dengan pendidikan. Pendidikan berarti bimbingan yang diberikan seseorang terhadap orang lain untuk mencapai tujuan tertentu. Pada umumnya semakin tinggi pendidikan seseorang maka semakin mudah pula dalam menerima informasi (Simbulah, 2012). Faktor lain yang juga mempengaruhi kurangnya pengetahuan responden tentang risiko pernikahan dini yaitu karena pengalaman pribadi maupun orang lain. Hal ini sesuai dengan teori yang mengatakan pengalaman pribadi juga dapat digunakan sebagai upaya memperoleh pengetahuan dengan cara mengulang kembali pengalaman yang pernah diperoleh dalam memecahkan permasalahan yang dihadapi di masa lalu (Sariyono, 2007).

Permasalahan yang dialami oleh remaja umumnya dikarenakan adanya krisis identitas tanpa adanya faktor pendukung dan sumber informasi yang jelas dalam memberikan ketersediaan layanan pada kelompok remaja (BKKBN, 2010). Banyak faktor yang menjadi penyebab perilaku pernikahan dini di kalangan remaja, diantaranya kurangnya pengetahuan tentang seks dan kesehatan reproduksi, latar belakang lingkungan, kurang pengawasan, dan media massa. Kurangnya fasilitas dan saranasarana konseling kesehatan reproduksi remaja yang masih terbatas dan peran orang tua serta masyarakat dalam memberikan pendidikan kesehatan reproduksi kepada anak dirasa masih kurang (Nour, 2009). Kondisi tersebut akan mengakibatkan permasalahan pada pemenuhan kesehatan reproduksi remaja, sehingga perlu perhatian dan penanganan khusus dari unit pelayanan kesehatan terutama perawat yang bekerja di dinas kesehatan dan puskesmas.

Berdasarkan data tabel 1. dapat disimpulkan bahwa penyebab tingkat pengetahuan responden dalam kategori cukup dikarenakan rendahnya tingkat pendidikan dan faktor perekonomian keluarga yang menyebabkan remaja putus sekolah bahkan 
tidak melanjutkan pendidikan karena ekonomi yang kurang sehingga tidak mampu membiayakan anaknya untuk melanjutkan pendidikan, selanjutnya darimana informasi yang di dapat seperti dari pengalaman dari teman, media cetak, dan media massa. Selain peyebab diatas dapat juga disebabkan oleh seberapa besar rasa ingin tahu mereka mengenai hal-hal yang berkaitan dengan kesehatan reproduksi, risiko pernikahan dini, dan kehamilan tidak diinginkan (KTD), serta pengamatan mereka terhadap risiko pernikahan dini dengan melihat keadaan sekeliling lingkungan mereka dengan mereka seharusnya dapat menyimpulkan kejadian yang telah diamati oleh responden.

Perilaku seksual remaja memiliki kecenderungan sikap yang permisif pada remaja terhadap perilaku seks bebas atau perilaku seks di luar nikah. Sikap permisif remaja terhadap perilaku seks bebas didukung oleh terbatasnya pengetahuan remaja tentang kesehatan reproduksi remaja (Sariyono, 2007). Survei Dasar Kesehatan Reproduksi Republik Indonesia (SDKRI) di Kota Manado tahun 2000 menunjukkan pengetahuan dasar yang dimiliki responden mengenai kesehatan reproduksi relatif terbatas. Keadaan ini dapat diketahui dari $57,78 \%$ responden tidak mengetahui pengertian seksualitas. Pengetahuan remaja tentang kesehatan reproduksi sangat rendah yaitu sekitar $75 \%$. Rendahnya pengetahuan remaja tersebut berdampak pada perilaku seksual remaja menuju ke arah yang sangat membahayakan (Kemenkes RI, 2013; Novianti, 2014).

Hasil survei lain tentang pernikahan dini yang dilakukan pada 200 responden yang melakukan pernikahan dini di Jawa Tengah menunjukkan bahwa $36,2 \%$ dari jumlah responden yang melakukan pernikahan dini menyatakan bahwa alasan melakukan hal tersebut karena ungkapan sayang, rasa memiliki, keakraban dan perhatian (KPP\&PA, 2012).

Tingginya rasio pernikahan dini dipengaruhi oleh konsep diri, kontrol diri, usia, jenis kelamin, harapan terhadap pendidikan dan nilai -nilai di sekolah, proses keluarga, kelas sosial ekonomi, kualitas lingkungan sekitar tempat tinggal dan pengaruh kelompok teman sebaya (Nour, 2009). Kelompok teman sebaya merupakan faktor penting yang mempengaruhi pernikahan dini, mengingat semakin dominannya peran kelompok sebaya daripada orangtua pada usia-usia remaja atau menjelang dewasa, dibandingkan masa-masa sebelumnya (Sariyono, 2007). Remaja secara perkembangan sosial akan terpengaruh oleh kelompok sebayanya dan mulai keluar dari kehidupan keluarganya (Novianti, 2014). Remaja mulai memasuki kehidupan sosial dalam populasi remaja secara keseluruhan.

Menurut asumsi peneliti yang dilakukan oleh peneliti di Lingkungan RW 06 Pudak Payung ditemukan responden yang berpengetahuan baik dikarenakan responden sudah pernah mendengar penjelasan tentang risiko pernikahan yang terlalu dini atau di usia muda yaitu usia 13-20 tahun dan mengikuti penyuluhan mengenai kesehatan reproduksi pada usia remaja, penjelasan tersebut mereka peroleh dari tenaga kesehatan yang melakukan penyuluhan tersebut saat responden bersekolah di SMP dan SMA selain itu di Kelurahan Pudak Payung juga pernah di lakukan pemberdayaan remaja oleh mahasiswa dari Universitas Ngudi Waluyo yang berkerjasama dengan pihak Puskesmas Pudak Payung dan bidan setempat, sehingga memberi respon atau dampak positif kepada responden yaitu remaja Pudak Payung yang berumur 13-20 tahun dengan hasil remaja tersebut berpengetahuan baik.

Menurut asumsi peneliti, responden berpengetahuan cukup dikarenakan beberapa hambatan yang menyebabkan remaja dengan berpengetahuan cukup yaitu sebagian responden yang masih sedikit pengetahuannya yang diperoleh remaja tentang dampak yang ditimbulkan dari pernikahan di usia muda atau yang terlalu dini baik dari, media cetak, media massa maupun pengalaman dari teman-teman atau keluarga serta penjelasan dari petugas kesehatan yang kurang jelas dalam memberikan paparan materi ataupun teori mengenai KTD (Kehamilan Tidak Diduga) dan Pernikahan di 
usia dini, karena sebagian responden kurang memahami dan daya ingat yang kurang. Dengan demikian, pengetahuan remaja tentang Risiko Pernikahan Dini terbatas. Dalam permasalahan tersebut menyebabkan pengetahuan remaja tergolong mayoritas cukup. Penjelasan di atas dalam hal ini sesuai penelitian (Desiyanti, 2015).

Menurut asumsi peneliti responden berpengetahuan kurang dikarenakan kurangnya pengamatan responden tentang risiko pernikahan dini, karena kurang rasa ingin tahu mengenai informasi risiko apa saja yang terjadi jika melakukan pernikahan dini dan dampak yang diterima baik dampak pada diri seseorang yang melakukan pernikahan dini maupun dampak untuk orang lain di sekitar pelaku penikahan dini. Hal ini sesuai dengan penelitian (Novianti, 2014).

Faktor lainnya yaitu kurang berkembangnya cara berpikir responden, karena perkembangan cara berpikir seseorang dapat berpengaruh terhadap pengetahuan yang dimiliki seseorang. Kemudian dapat pula di pengaruhi oleh lingkungan yang tidak menganggap penting pengetahuan mengenai risiko pernikahan dini serta anggapan dari masyarakat yang tabu jika membahas atau mencari tahu mengenai kesehatan reproduksi atau mengenai risiko pernikahan dini. Hal ini dibuktikan berdasarkan penilitian yang dilakukan oleh Stang (2011) yang menyebutkan bahwa cara berpikir seseorang sangat erat kaitannya dengan rendah tingginya pengetahuan seseorang.

Melihat dari hasil pengumpulan data yang dilakukan oleh peneliti bahwa responden mayoritas berpengetahuan cukup karena dipengaruhi kurangnya kemampuan responden dalam mengingat materi tentang risiko pernikahan dini walaupun responden sebelumnya telah membaca atau menerima informasi tentang risiko perkawinan dini dalam kehamilan. Kemampuan responden dalam mengingat sesuatu termasuk dalam tingkat pengetahuan yaitu tingkat tahu.

Rendahnya tingkat pendidikan remaja dan kurangnya pendidikan seks pada remaja menyebabkan kurangnya pengetahuan remaja tentang pernikahan dini.Tidak dapat dipungkiri semakin tinggi pendidikan seseorang semakin mudah mendapat informasi maka makin banyakpula pengetahuan yang dimiliki. Upaya yang dapat dilakukan yaitu dengan memberikan penyuluhan tentang risiko pernikahan dini.

Berdasarkan hasil penelitian, peneliti berasumsi bahwa pendidikan turut menyebabkan responden dilakukan pernikahan dini, karena responden yang berpendidikan dasar atau menengah lebih cenderung untuk dinikahkan oleh orang tuanya, di bandingkan dengan responden yang berpendidikan tinggi, dalam kekosongan waktu tanpa pekerjaan membuat mereka akhirnya melakukan hal-hal yang tidak produktif, salah satunya adalah menjalin hubungan dengan lawan jenis, yang jika diluar kontrol membuat kehamilan diluar nikah. Hal ini didasarkan pada penelitian (Utami, 2015). Hasil penelitian ini menyebutkan bahwa sebenarnya jika pendidikan orang tua meningkat dan memikirkan dampak negatif yang terjadi pada anak yang menikah di usia dini, maka pernikahan di usia dini itu tidak akan terjadi begitu banyak. Beberapa hasil observasi yang kami dapat menyatakan bahwa pendorong terjadinya pernikahan dini adalah keinginan orang tua, sebab keinginan orang tua menikahkan anaknya adalah hal yang penting karena dikhawatirkan akan terjadi hal yang tidak diinginkan, tetapi alasan itu juga tidak dibenarkan oleh sebagian masyarakat, karena bagi sebagian mereka menikahkan anaknya di usia muda itu disebabkan faktor ekonomi. Dalam hal memilih pasangan ini, orang tua dilarang memaksa anak-anaknya untuk dijodohkan dengan pria atau wanita pilihannya, melainkan diharapkan membimbing anakanaknya agar dapat memilih pasangan yang sesuai dengan ajaran agama.

Orang tua anak perempuan cenderung segera menikahkan anaknya karena menurut orang tua anak gadis ini bahwa sudah tidak ada perawan lagi dan hal ini menjadi aib, dewasa ini kebutuhan sehari-hari dirasakan sangat berat dengan naiknya harga kebutuhan pokok dan 
banyaknya anak yang putus sekolah dan tidak mampu melanjutkan kejenjang pendidikan sehingga mereka banyak terjadi pernikahan di usia muda, orang tua yang tidak sanggup menyekolahkan anaknya sehingga ia cepatcepat dinikahkan, juga karena kurangnya kemauan untuk melanjutkan sekolah maka satusatunya jalan keluar adalah dinikahkan secepatnya.

Dalam segi pengetahuan berdasarkan hasil pengetahuannya menunjukan dari 30 responden memiliki pengetahuan cukup sejumlah 23 responden dan yang berpengetahuan kurang sejumlah 5 responden. Remaja-remaja di Kelurahan Pudak Payung tidak dibekali dengan pengetahuan yang cukup, dan akibatnya terjadi pernikahan di usia muda yaitu usia remaja. Sebagai salah satu upaya pencegahan perilaku pernikahan dini maupun pergaulan seks bebas yang menjadi pendorong terjadinya pernikahan dini yaitu pentingnya peran orang tua dengan memberikan arahan dan bimbingan kepada anaknya supaya dapat dapat dipantau atau diamati sehingga tidak lepas kendali ke arah yang negatif seperti pergaulan bebas dari tahun ke tahun yang semakin bertambah parah memberikan pengaruh buruk. Pengetahuan yang diperoleh responden merupakan penyebab dari terjadinya dilakukan pernikahan pada usia dini, karena pengetahuan mempunyai hubungan yang terlalu berpengaruh terhadap penyebab pernikahan usia dini. Pengetahuan remaja di Kelurahan Pudak Payung kurang kepahamannya dalam hal pernikahan dini, sebenarnya dari suatu pernikahan yang dilakukan, ketidakbahagiaan dalam pernikahan, sebagian besar pasangan yang memasuki jenjang pernikahan tidak mempunyai persiapan jiwa dalam arti yang sesungguhnya.

Dan ada pula yang menyatakan bahwa dampak anak yang dinikahkan diusia dini adalah dampak psikologi, jika anak dinikahkan di bawah umur maka dalam menjalani kehidupan rumah tangga tidak akan harmonis, mereka lebih sering bertengkar dan akhirnya terjadi perceraian, sebab emosi dan pemikiran mereka belum siap. Dan usia matang atau kesiapan umur secara psikologi adalah usia bagaimana kita perpola sikap, pola perasaan, pola pikir dan prilaku sehingga pasangan tersebut mampu menjaga egoisme serta sikap dalam rumah tangga dan disanalah terjalin pasangan yang harmonis (Tati, 2017). Selain implikasi psikologis, ada pula dampak yang harus diperhatikan bagi tiap orang tua terhadap anaknya yaitu dampak biologis, sebab anak yang belum cukup usia maka organ reproduksinya belum siap dibuahi, karena masamasa itu adalah masa proses menuju kematangan. Jika anak dipaksa menikah di usia dini, maka hal itu bisa membahayakan nyawa ibu dan bayi, seperti paparan sebelumnya (Nurhajati, 2012).

Implikasi dari pernikahan di usia remaja antara lain yaitu akan mempengaruhi nasib kelangsungan hidup rumah tangga pasangan usia dini tersebut. Di lingkungan masyarakat, tampaknya tidak banyak orang tua yang menyesal telah menikahkan anak-anaknya di usia dini. Padahal mereka sering melihat bahtera rumah tangga anaknya yang sering diwarnai konflik dan pertengkaran karena persoalan sepele, yang bisa jadi akan berujung perceraian. Data yang peneliti temukan tentang beberapa implikasi pernikahan dini di antaranya adalah bahtera rumah tangga mereka tidak hamonis, sering bertengkar, pisah ranjang bahkan sampai bercerai. Hal ini semestinya tidak harus terjadi jika orang tua dan anak-anak memiliki pengetahuan yang memadahi tentang makna sebuah pernikahan (Nour, 2009). Fenomena ini seperti yang terjadi di Pandan, penelitian yang dilakukan oleh Desiyati (2015) menunjukkan bahwa dampak dari pernikahan dini adalah pertengkaran dan percekcokan yang disebabka oleh emosi masing-masing yang belum stabil, berakibat perceraian meski akhirnya menikah lagi, berdampak pada masalah kesehatan seksual dan kesehatan reproduksi bagi perempuan, sehingga menghilangkan kesempatan bagi mereka untuk menempuh pendidikan yang lebih tinggi.

Melihat berbagai macam dampak yang akan terjadi, maka pengetahuan risiko remaja tentang pernikahan dini sangat penting 
diberikan untuk meningkatkan pengetahuan mereka melalui orang tua, sekolah maupun lingkungan masyarakat. Orang tua seharusnya tetap terus mengingatkan informasi yang sudah diterima anaknya tentang bahaya pernikahan dini pada kesehatan reproduksinya, dan mengarahkan atau membimbing supaya tetap pada jalur yang seharusnya. Selain itu, remaja sudah sewajarnya memiliki sikap yang bertanggung jawab dalam bertindak, selain itu remaja mampu merencanakan masa depan yang baik dan mampu membuat suatu keputusan dengan bijak agar pernikahan dini tidak terjadi dan dapat terhindar dari faktor-faktor yang dapat berpengaruh buruk terhadap kesehatan reproduksinya yaitu pernikahan dini dan Kehamilan Tidak Diinginkan (KTD).

\section{PENUTUP}

Simpulan dari penelitian ini yaitu tingkat pengetahuan remaja di lingkungan RW 06 Kelurahan Pudak Payung pada tentang risiko pernikahan dini tergolong mayoritas cukup. Penyebab rendahnya pengetahuan responden terhadap permasalahan pernikahan dini yaitu karena kurangnya pengamatan remaja mengenai dampak yang akan ditimbulkan dari pernikahan di usia muda, kurangnya informasi yang didapat, serta kurangnya tingkat pemahaman responden terhadap penjelasan yang diberikan melalui penyuluhan dari tenaga kesehatan dan pendidikan di SMP dan SMA. Adapun penyebab responden yang tergolong dalam berpengetahuan cukup dikarenakan masih sedikitnya pengetahuan yang diperoleh remaja tentang risiko pernikahan dini, baik dari media cetak, media masa dan pengalaman dari teman-teman keluarga meupun petugas kesehatan.

Saran bagi peneliti selanjutnya diharapkan dapat meneliti lebih lanjut mengenai intervensi yang harus dilakukan untuk meningkatkan pengetahuan kesehatan reproduksi pada remaja, khususnya usia 13-19 tahun dengan pendekatan kuantitatif untuk memperoleh pemahaman yang lebih luas, dalam dan bervariasi.

\section{DAFTAR PUSTAKA}

Anas, S. H. 2010. Sketsa Kesehatan Reproduksi Remaja. YINYANG, 5(1): 199-214

Bahar, A., Tarigan, G., Bangun, P. 2014. Identifikasi Faktor Pendorong Pernikahan Dini Dengan Metode Analisis Faktor. Saintia Matematika, 2(1): 1-11

BKKBN. 2010. Pendewasaan Usia Perkawinan dan HakHak Reproduksi bagi Remaja Indonesia. Jakarta: BKKBN

Dewi, D. A. D. K., Lubis, D. S. M. 2012. Tingkat Pengetahuan dan Sikap Remaja Putri tentang Kehamilan Usia Dini di Kota Denpasar. Skripsi. Badung: Universitas Udayana

Desiyanti. I. W. 2015. Faktor-faktor yang Berhubungan terhadap Pernikahan Dini pada Pasangan Usia Subur di Kecamatan Mapanget Kota Manado. JIKMU, 5(2): 270280

Diaz-Quijano, F.A., Martínez-Vega, R.A., Rodriguez-Morales, A.J. 2017. Association between the level of education and knowledge, attitudes and practices regarding dengue in the Caribbean region of Colombia. BMC Public Health, 18 (1): 143

Fadlyana, E., Larasaty, S. 2009. Pernikahan Usia Dini dan Permasalahannya. Sari Pediatri, 11(2): 136-41

Kemenkes RI. 2013. Riset Kesehatan Dasar Tahun 2013. Jakarta: Kemenkes RI

KPP\&PA. 2012. Profil Anak Indonesia tahun 2012. Jakarta: KPP\&PA

Nour, N. M. 2009. Child Marriage: A Silent Health and Human Right Issue. Women's Health in the Developing World, 2(1): 51-56

Novianti, S. 2014. Faktor Persepsi dan Dukungan Istri yang Berhubungan dengan Partisipasi KB Pria. FIK Universitas Siliwangi Tasikmalaya. Jurnal Kesehatan Komunitas Indonesia, 10(2): 1215

Nurhajati, L., Wardyaningrum, D. 2012. Komunikasi Keluarga dalam Pengambilan Keputusan Perkawinan di Usia Remaja. Jurnal Al-Azhar Indonesia Seri Pranata Sosial, 1(4): 236-248

Sariyono. 2007. Hubungan Antara Pengetahuan dan Sikap Pria Tentang Keluarga Berencana dengan Partisipasi Pria Dalam Pemakaian Metode Kontrasepsi Keluarga Berencana di Kabupaten Barito Kuala. Jurnal Ilmiah Kesehatan Keperawatan, 3 (1) :14-16

Stang, Mambaya, E. 2011. Faktor yang Berhubungan dengan Pernikahan Dini di Kelurahan Pangli 
Eka R.O., Fatehah R.A., Nandito M.M., Sigit A.W., Widya H.C. /Pengetahuan Risiko/HIGEIA 2 (2) (2018)

Kecamatan Sesean Kabupaten Toraja Utara. Jurnal MKMI, 7(1): 105-110

Sumbulah, U., Jannah, F. 2012. Pernikahan Dini dan Implikasinya terhadap Kehidupan Keluarga pada Masyarakat Madura (Perspektif Hukum Dan Gender). Egalita, 7(1): 83-101

Susilo,C.2014. Pernikahan Dini dalam Perspektif Kesehatan Reproduksi. The Indonesian Journal of Health Science, 112-120
Tati, S. D. W., dan Indarjo, S. 2017. Partisipasi Pasangan Pernikahan Dini Terhadap Program Keluarga Berencana. HIGEIA, 1(2): 65-76

Utami, F. T. 2015. Penyesuaian Diri Remaja Putri yang Menikah Muda. PSIKIS, 1(1) 11-21

Yulianti, R. 2010. Dampak yang Ditimbulkan Akibat Perkawinan Usia Dini. Pamator, 3(1): 1-5 